\title{
INCREASED PREFERENCE OF DARKLING BEETLES AKIS SUBTRICOSTATA REDTENBACHER, 1850 AND TRACHYDERMA PHILISTINA REICHE AND SAULCY, 1857 (COLEOPTERA, TENEBRIONIDAE) FOR VEGETATION WITH INCREASING TEMPERATURE
}

\author{
Omar K. Ismail and Aaron Bartholomew* \\ Department of Biology, Chemistry and Environmental Science, College of \\ Arts and Sciences, American University of Sharjah, Sharjah, United Arab \\ Emirates \\ *Corresponding author: abartholomew@aus.edu
}

Received Date: 25 May 2020, Accepted Date: 18 June 2020, Published Date: 24 June 2020

\section{ABSTRACT}

A square experimental arena with vegetation on one interior side was deployed in a Sharjah, United Arab Emirates desert. Individual darkling beetles (Coleoptera, Tenebrionidae) Akis subtricostata Redtenbacher, 1850 and Trachyderma philistina Reiche and Saulcy, 1857 were placed inside the arena at temperatures ranging between $27-49^{\circ} \mathrm{C}$. Whether they chose the vegetated side of the arena or not was recorded, as well as how long it took for them to reach the vegetated side, if they chose it. Both species preferred the vegetated side at all temperatures, and the chance of them choosing the vegetated side increased significantly with increasing temperature (logistic regression, $\mathrm{p}=0.0096$ and $\mathrm{p}=0.0003$ for $T$. philistina and A. subtricostata, respectively).

T. philistina and A. subtricostata always chose the vegetated side at temperatures above $31^{\circ}$ and $44^{\circ} \mathrm{C}$, respectively. Individual beetles that chose the vegetated side moved quickly and directly to it at temperatures above $30^{\circ} \mathrm{C}$. Below $30^{\circ} \mathrm{C}$, however, beetles tended to move slower and take more pauses within the arena. Time to reach the vegetated side declined significantly with increasing temperature (least-squares regression, $\mathrm{p}<0.00005$ for both species). A few individuals of both species died at the highest temperatures $\left(48-49^{\circ} \mathrm{C}\right)$.

Key words: Desert, Habitat choice, Refuge, Shrubs, Thermoregulation, United Arab Emirates

\section{INTRODUCTION}

Darkling beetles (Coleoptera, Tenebrionidae) are abundant, diverse, ecologically-important inhabitants of many arid and semi-arid environments worldwide (De los Santos et al., 2002; Saji and Al Dhaheri, 2011). Adults and larvae usually feed on dead plant and animal matter or 


\section{Increased preference of darkling beetles}

are phytophagous (Fattorini, 2000; Kaplin, 2019).Darkling beetles are preyed upon by a variety of predators (Bartholomew and El Moghrabi, 2018), and they are important links in desert food webs (Polis, 1991). The microbes within the guts of xerophilous darkling beetles break down dead plant material, so darkling beetles are also important for returning nutrients to desert soils (Ayal, 2007).

Darkling beetles living in hot deserts have evolved a variety of morphological, physiological and behavioural adaptations for surviving extreme temperatures (CloudsleyThompson, 2001). Physiologically, darkling beetles produce heat shock proteins, enzymes related to heat resistance and other cryoprotectant molecules in response to elevated temperatures (Qiu et al., 2013; Lu et al., 2014). Some species possess reflective elytra (Edney, 1971). Some species have relatively long legs compared with their body size, and some species also exhibit "stilting" behaviour at high temperatures; these adaptations keep their bodies away from the hot sands and increase convective cooling (Krasnov et al., 1996, Ward and Seely, 1996a). The most important adaptations many darkling beetle species possess for temperature regulation are behavioural; they may exhibit crepuscular and/or nocturnal activity patterns year-round, or only during the hottest months of the year (Ayal and Merkl, 1994). These insects are usually found in burrows during the day, they may bury themselves in response to high temperatures (Ward and Seely, 1996b) and they use cooler microhabitats, including vegetation, as an important way to regulate their temperatures and cool down (Shelef and Groner, 2011).

Various studies have shown that darkling beetles tend to prefer vegetation over open sands in desert environments, but the reasons for this preference are not always clear; they may prefer vegetation because of greater food resources, better protection from predators, better oviposition sites, greater availability of animal burrows, higher relative humidity and because vegetation helps them regulate their temperatures (cooler during the day and slightly warmer at night) (Stapp, 1997; Shelef and Groner, 2011). Darkling beetles must regulate their temperatures both for themselves and for the microbes within their guts, higher temperatures may lead to higher microbial activity levels for digestion, but temperatures that are too high can be lethal for the beetles (Crawford, 1988).

This study was performed in order to directly observe the effects of temperature on UAE darkling beetle habitat preference, and to confirm the critical importance of vegetation in providing beetles with refuge from high temperatures. No other field study has directly observed increased beetle habitat preference for natural vegetation in response to increasing temperatures.

\section{MATERIALS AND METHODS}

The experimental trials took place in the fall of 2018. Trials were conducted in a desert area in Sharjah, the United Arab Emirates containing patchy shrub vegetation at approximately 25.313743 N, 55.501176 E. Experimental trials were conducted in the morning, and beetles used in the trials were trapped the night before in this area. Most beetles spent less than 12 
hours in a trap before their trial, and no beetle spent more than 24 hours in a trap before their trial.

The arena was $2 \times 2 \times 1.2 \mathrm{~m}$. It was created with white cloth "blackout" curtains secured to a PVC pipe frame. The top of the arena was covered with a dark plastic tarp secured with bungee cords. The curtains on the inside of the arena were clean and smooth during experimental trials, and no folds of cloth protruded into the arena under the frame and no direct sunlight entered the arena. Although there was no direct sunlight entering the arena, the curtains did allow some light through the cloth material, which created a dimly-lit interior with diffuse light, similar to what beetles would naturally experience at dusk or dawn. The curtains and plastic tarp ensured that there were no differences in light intensity in different parts of the arena, which may have influenced the beetles' choices. Live branches of Hamada elegans, which is the dominant shrub in the area, were attached to one interior side of the arena with thin ropes, mimicking the approximate height and width of the shrubs in the surrounding desert.

Each trial day the arena was set up in a different flat area and the position of the vegetated side was changed. After assembling the arena, large sticks, stones, vegetation, etc. were removed from the sand of the arena floor, and the center of the arena was marked. A thermometer was placed inside the arena near the vegetated side approximately $1 \mathrm{~cm}$ above the sand. Over the trial months, the arena was deployed on different days and at different times in the morning and thus trials were conducted over a wide range of naturally-occurring sand temperatures.

The species Akis subtricostata (91 individuals) and Trachyderma philistina (70 individuals) were used because only these species were captured frequently enough to generate sufficient data for analysis. Beetles were identified using Schawaller (2010). A trial with an individual beetle began by placing the beetle at the center of the arena under a clear plastic bowl. The beetle was left under the bowl for 2 minutes. After 2 minutes, the bowl was lifted by a rope that came down through the center of the plastic tarp, and an observer would watch the beetle through a small peephole cut out of the vegetated side. The observer's silhouette was not visible through the blackout curtains. The observer recorded whether the individual beetle first encountered the vegetated side or one of the three unvegetated sides of the arena, how long it took for the beetle to reach a side, the temperature immediately after each individual trial and any interesting observations.

Logistic regressions were used for each species separately to test whether the odds of a beetle choosing the vegetated side increased significantly with increasing temperature. For those beetles that chose the vegetated side, least-squares regressions were used for each species separately to test whether the time to reach the vegetated side decreased significantly with increasing temperature. The time data (in seconds) was square-root transformed to meet the assumptions of the least-squares regression. 


\section{Increased preference of darkling beetles}

\section{RESULTS AND DISCUSSION}

The results of the logistic regression statistical tests were highly significant for both beetle species, as the likelihood that the two beetle species chose the vegetated side over any of the three unvegetated sides increased with increasing temperature (Tabs. 1, 2 and Diag. $1 \mathrm{a}, \mathrm{b}$ ). For those beetles that chose the vegetated side of the arena, the results of the least-squares linear regressions demonstrated that the amount of time it took them to reach the vegetated side decreased significantly with increasing temperature for both species (Tabs. 3, 4; Diag. $1 \mathrm{c}$, d).

Table (1): The results of the logistic regression for A. subtricostata choosing the vegetated side versus unvegetated sides of the arena.

\begin{tabular}{|c|c|c|c|c|c|}
\hline Variable & Coeff. & Std. Err. & $\mathrm{p}$ & Odds Ratio & $\begin{array}{c}\text { 95\% Confidence } \\
\text { Limits }\end{array}$ \\
\hline Temperature & 0.1661 & 0.0464 & 0.0003 & 1.1807 & $1.0781-1.2931$ \\
\hline Intercept & -4.7461 & 1.5264 & 0.0019 & \\
\multicolumn{7}{|c}{ Overall Model Fit: Chi Square $=18.0816 ; \mathrm{df}=1 ; \mathrm{p}<0.00005$}
\end{tabular}

Table (2): The results of the logistic regression for $T$. philistina choosing the vegetated side versus unvegetated sides of the arena.

\begin{tabular}{|c|r|c|c|c|c|}
\hline Variable & Coeff. & Std. Err. & $\mathrm{p}$ & Odds Ratio & $\begin{array}{c}95 \% \text { Confidence } \\
\text { Limits }\end{array}$ \\
\hline Temperature & 0.4805 & 0.1854 & 0.0096 & 1.6169 & $1.1242-2.3255$ \\
\hline Intercept & -13.2734 & 5.3897 & 0.0138 & \multicolumn{2}{|c}{} \\
\cline { 1 - 4 } & &
\end{tabular}

Overall Model Fit: Chi Square $=22.2072 ; \mathrm{df}=1 ; \mathrm{p}<0.00005$

Table (3): The results of the least-squares linear regression for the amount of time (sec.) it took A. subtricostata beetles to choose the vegetated side of the arena versus temperature. The time data were square-root transformed to meet the assumptions of the regression.

\begin{tabular}{|c|c|c|c|c|c|}
\hline & df & SS & MS & F & p \\
\hline Regression & 1 & 177.5392 & 177.5392 & 77.5406 & $\mathrm{p}<0.00005$ \\
\hline Residual & 64 & 146.5363 & 2.2896 & \multicolumn{2}{|c}{} \\
\cline { 1 - 3 } Total & 65 & 324.0755 & \multicolumn{2}{|c}{} \\
\cline { 1 - 4 } & & &
\end{tabular}

Adjusted R-squared $=0.541$ 
Ismail and Bartholomew
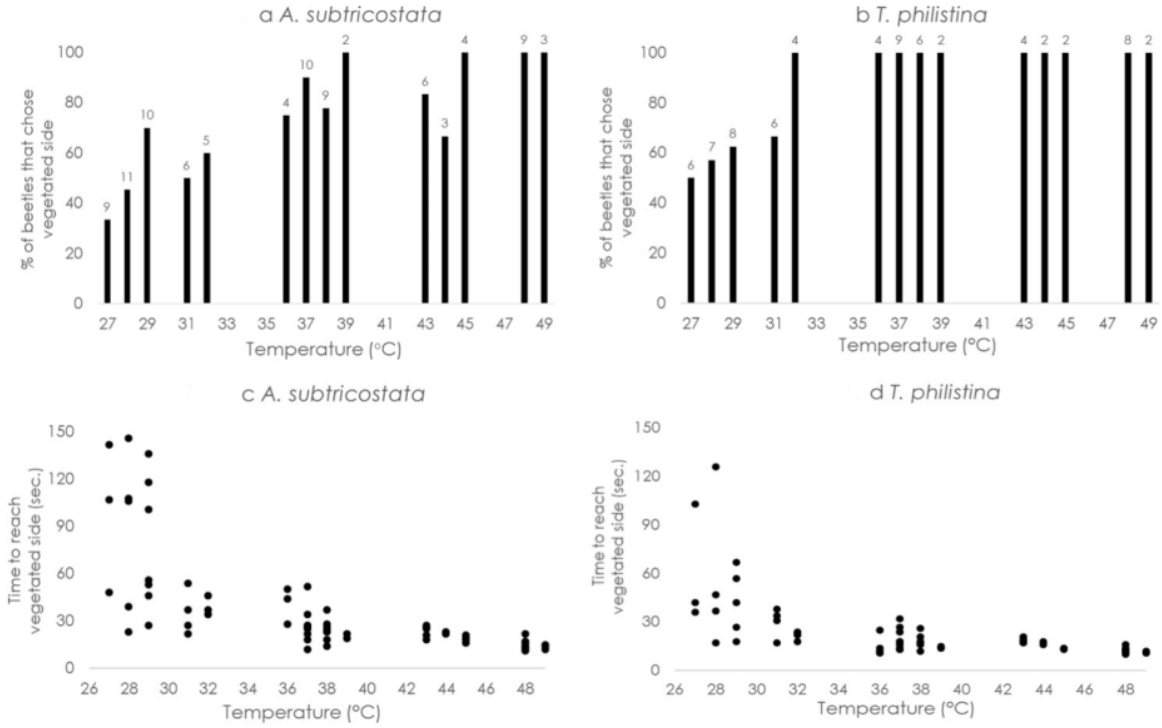

Diagram (1): The percentage of A. subtricostata (a) and T. philistina (b) that chose the vegetated side of the experimental arena over the three unvegetated sides at different temperatures. The number above each bar is the number of individual beetles used at that temperature. If beetles chose the vegetated side of the arena, the amount of time it took them to reach the vegetated side for A. subtricostata (c) and T. philistina (d).

Table (4): The results of the least-squares linear regression for the amount of time (sec.) it took T. philistina beetles to choose the vegetated side of the arena versus temperature. The time data were square-root transformed to meet the assumptions of the regression.

\begin{tabular}{|c|c|c|c|c|c|}
\hline & df & SS & MS & F & p \\
\cline { 1 - 4 } Regression & 1 & 63.1997 & 63.1997 & 44.0822 & $\mathrm{p}<0.00005$ \\
\hline Residual & 57 & 81.7197 & 1.4337 & \multicolumn{2}{|c}{} \\
\cline { 1 - 3 } Total & 58 & 144.9194 & \multicolumn{2}{|c}{} \\
\cline { 1 - 3 } & & &
\end{tabular}

Adjusted R-squared $=0.426$

Clearly, temperature affected the habitat choice behaviour of these two darkling beetle species, indicating the importance of desert shrubs in providing them with refuges from extreme temperatures. As the temperature increased, the likelihood that beetles chose the vegetated side of the arena increased significantly (Tabs. 1,2), and for those beetles that chose the vegetated side, they moved to the vegetated side significantly quicker with increasing temperature (Tabs. 3, 4). Diagrams 1a and 1c indicate that $A$. subtricostata chose 


\section{Increased preference of darkling beetles}

and moved quickly to the vegetated side $100 \%$ of the time at temperatures of $45{ }^{\circ} \mathrm{C}$ and above. Between 31 and $44{ }^{\circ} \mathrm{C}$, A. subtricostata did not always choose the vegetated side, but if they did choose the vegetated side, they moved to the vegetated side quickly (Diag. 1a, c). At temperatures of $29^{\circ} \mathrm{C}$ or below, A. subtricostata did not always choose the vegetated side, and even if they did choose the vegetated side they frequently wandered around the arena or took pauses, rather than heading directly to the vegetated side (Diag. 1a, c). T. philistina chose vegetation $100 \%$ of the time, and moved to the vegetated side quickly, at temperatures of $32^{\circ} \mathrm{C}$ and above (Diag. $1 \mathrm{~b}, \mathrm{~d}$ ). At lower temperatures, T. philistina did not always choose the vegetated side, and even if they did choose the vegetated side they did not consistently move quickly towards the vegetated side (Diag. $1 \mathrm{~b}, \mathrm{~d}$ ). These results may indicate that $A$. subtricostata has higher physiological tolerances for high temperatures than T. philistina. This could be investigated further, to determine if any differences in temperature tolerances contribute to differences in habitat use or activity patterns in these two species.

It should be noted that even at lower temperatures $\left(\leq 31{ }^{\circ} \mathrm{C}\right.$, for example) both beetle species chose the vegetated side of the arena more than $25 \%$ of the time, which is what would be expected by chance alone. This may indicate that temperature is not the only factor that caused beetles to prefer vegetated habitats. On the hottest days $\left(48\right.$ and $\left.49{ }^{\circ} \mathrm{C}\right)$ the beetles climbed up the vegetation, perhaps to escape the extremely hot boundary layer just above the sand surface (Marsh 1985), and some beetles died during the brief experimental trials. Roberts et al. (1991) found that the critical thermal maximum for several species of Namib desert darkling beetles ranged between $48-51{ }^{\circ} \mathrm{C}$, similar to our results, and their median preferred temperatures ranged from $29-40{ }^{\circ} \mathrm{C}$. Maeno et al. (2014) observed mortality in the darkling beetle Pimelia senegalensis (Olivier, 1775) from the Sahara at temperatures above $50{ }^{\circ} \mathrm{C}$.

Several field studies obtained results that suggest darkling beetles prefer shrubs because they provide refuges from high temperatures (Mazía et al., 2006; Shelef and Groner, 2011; Liu et al., 2012; Bartholomew and El Moghrabi, 2018). Unlike our study, these studies did not directly observe beetle behaviour, but relied on pit trapping instead. The results of our experiment support the similar results of Parmenter et al. (1989a) who found that increasing temperature caused four species of darkling beetles (genus Eleodes) to increase their preference for the sides of an arena with a shrub silhouette drawn on them. Parmenter et al. (1989a) found that at $21^{\circ} \mathrm{C}$ none of the four species preferred vegetation. At $29{ }^{\circ} \mathrm{C}$, two of the species preferred vegetation, but they did not consistently move quickly to the vegetated side. At $36{ }^{\circ} \mathrm{C}$, all four species preferred vegetation and moved quickly towards it. At $36{ }^{\circ} \mathrm{C}$, several individuals died due to hyperthermia. (Parmenter et al., 1989b) found that different darkling beetle species had different preferred temperatures in nature. Two species that normally lived in cooler microhabitats below large shrubs had preferred temperatures of 21 $22{ }^{\circ} \mathrm{C}$, whereas species normally found in hotter, short-shrub microhabitats had preferred temperatures of $27^{\circ} \mathrm{C}$. Whicker and Tracy (1987) also found that different darkling beetle species had different preferred temperatures and that the different species exhibited their maximum activity levels at their preferred temperatures. 
Desert shrubs provide important temperature refuges and critical habitat for darkling beetles and a variety of other desert fauna, and protecting desert vegetation should be a priority for conservation efforts in arid countries (Mazía et al., 2006; Liu et al., 2012). Unfortunately, in the UAE, desert vegetation is frequently overgrazed by camels, and destroyed by development and off-road vehicles (Bartholomew and El Moghrabi, 2018). Abu Dhabi Emirate in the UAE has recently implemented protected reserves surrounded by fences that exclude camels and vehicles, and the results are promising, with much higher densities of vegetation and more fauna recorded inside these reserves compared with the surrounding unprotected desert (Al Dhaheri et al., 2017; Bartholomew and El Moghrabi, 2018). Further efforts to conserve shrub vegetation in the UAE and other arid countries are warranted, to help protect desert biodiversity.

\section{CONCLUSION}

The results of this experiment demonstrate the importance of desert shrubs to darkling beetles, because the shrubs provide the beetles with refuges from extreme temperatures. There was a highly significant positive relationship between increasing temperature and beetles' likelihood to choose vegetation, and also a highly significant negative relationship between temperature and the amount of time it took beetles to reach the vegetation.

\section{ACKNOWLEDGEMENT}

The authors would like to thank Dana Hammoud, School of Biosciences, University of Birmingham, the UK for her help with the field work and the anonymous reviewers who improved the manuscript.

\section{LITERATURE CITED}

Al Dhaheri, S., Javed, S., Alzahlawi, N., Binkulaib, R., Cowie, W., Grandcourt, E. and Kabshawi, M. 2017. Abu Dhabi Emirate habitat classification and protection guideline. Environment Agency Abu-Dhabi (EAD), 76 pp.

Ayal, Y. 2007. Trophic structure and the role of predation in shaping hot desert communities. Journal of Arid Environments, 68: 171-187.

Ayal, Y. and Merkl, O. 1994. Spatial and temporal distribution of tenebrionid species (Coleoptera) in the Negev Highlands, Israel. Journal of Arid Environments, 27: 347361.

Bartholomew, A. and El Moghrabi, J. 2018. Seasonal preference of darkling beetles (Tenebrionidae) for shrub vegetation due to high temperatures, not predation or food availability. Journal of Arid Environments, 156: 34-40.

Cloudsley-Thompson, J. 2001. Thermal and water relations of desert beetles. Naturwissenschaften, 88: 447-460. 
Crawford, C. 1988. Nutrition and habitat selection in desert detritivores. Journal of Arid Environments, 14: 111-121.

De los Santos, A., De Nicolas, J. and Ferrer, F. 2002. Habitat selection and assemblage structure of darkling beetles (Col. Tenebrionidae) along environmental gradients on the Island of Tenerife (Canary Islands). Journal of Arid Environments, 52: 63-85.

Edney, E. 1971. The body temperature of tenebrionid beetles in the Namib Desert of Southern Africa. Journal of Experimental Biology, 55: 253-272.

Fattorini, S. 2000. Dispersal, vicariance and refuges in the Anatolian Pimeliinae (Coleoptera, Tenebrionidae): remarks on some biogeographical tenets. Biogeographia-The Journal of Integrative Biogeography, 21: 355-398.

Kaplin, V. 2019. Distribution, life forms and ecological peculiarities of darkling beetles (Coleoptera, Tenebrionidae) of the Eastern Kara Kum. Entomological Review, 99: 987-1004.

Krasnov, B., Ward, D. and Shenbrot, G. 1996. Body size and leg length variation in several species of darkling beetles (Coleoptera: Tenebrionidae) along a rainfall and altitudinal gradient in the Negev Desert (Israel). Journal of Arid Environments, 34: 477-89.

Liu, J., Li, F., Liu, C. and Liu, Q. 2012. Influences of shrub vegetation on distribution and diversity of a ground beetle community in a Gobi Desert ecosystem. Biodiversity and Conservation, 21: 2601-2619.

Lu, X., Li, J., Yang, J., Liu, X. and Ma, J. 2014. De novo transcriptome of the desert beetle Microdera punctipennis (Coleoptera: Tenebrionidae) using illumina RNA-seq technology. Molecular Biology Reports, 41: 7293-7303.

Maeno, K., Nakamura, S. and Babah, M. 2014. Nocturnal and sheltering behaviours of the desert darkling beetle, Pimelia senegalensis (Coleoptera: Tenebrionidae), in the Sahara Desert. African Entomology, 22: 499-504.

Mazía, C., Chaneton, E. and Kitzberger T. 2006. Small-scale habitat use and assemblage structure of ground-dwelling beetles in a Patagonian shrub steppe. Journal of Arid Environments, 67: 177-194.

Marsh, A. 1985. Thermal responses and temperature tolerance in a diurnal desert ant, Ocymyrmex barbiger. Physiological Zoology, 58: 629-636.

Parmenter, R., Parmenter, C. and Cheney, C. 1989 a. Factors influencing microhabitat partitioning among coexisting species of arid-land darkling beetles (Tenebrionidae): 
Ismail and Bartholomew

behavioral responses to vegetation architecture. The Southwestern Naturalist, 34: 319329.

Parmenter, R., Parmenter, C. and Cheney, C. 1989 b. Factors influencing microhabitat partitioning in arid-land darkling beetles (Tenebrionidae): temperature and water conservation. Journal of Arid Environments, 17: 57-67.

Polis, G. 1991. Complex trophic interactions in deserts: an empirical critique of food-web theory. The American Naturalist, 138: 123-155.

Qiu, L., Mao, X., Hou, F. and Ma, J. 2013. A novel function-thermal protective properties of an antifreeze protein from the summer desert beetle Microdera punctipennis. Cryobiology, 66: 60-68.

Roberts, C., Seely, M., Ward, D., Mitchell, D. and Campbell, J. 1991. Body temperatures of Namib Desert tenebrionid beetles: their relationship in laboratory and field. Physiological Entomology, 16: 463-475.

Saji, A. and Al Dhaheri, S. 2011. Ecological distribution and seasonality of darkling beetles (Coleoptera: Tenebrionidae) in the Western Region of Abu Dhabi, UAE. Middle East Journal of Scientific Research, 9: 704-710.

Schawaller, W. 2010. Order Coleoptera, family Tenebrionidae (with the exception of the subfamily Alleculinae). In: van Harten, A. (ed.) Arthropod Fauna of the UAE, Volume 3, Dar Al Ummah, United Arab Emirates, p 253 -278.

Shelef, O. and Groner, E. 2011. Linking landscape and species: effect of shrubs on patch preference of beetles in arid and semi-arid ecosystems. Journal of Arid Environments, 75: $960-967$.

Stapp, P. 1997. Microhabitat use and community structure of darkling beetles (Coleoptera: Tenebrionidae) in shortgrass prairie: effects of season shrub and soil type. American Midland Naturalist, 137: 298-311.

Ward, D. and Seely, M. 1996 a. Adaptation and constraint in the evolution of the physiology and behavior of the Namib Desert tenebrionid beetle genus Onymacris. Evolution, 50: 1231-1240.

Ward, D. and Seely, M. 1996 b. Behavioral thermoregulation of six Namib Desert tenebrionid beetle species (Coleoptera). Annals of the Entomological Society of America, 89: 442451.

Whicker, A. and Tracy, C. 1987. Tenebrionid beetles in the shortgrass prairie: daily and seasonal patterns of activity and temperature. Ecological Entomology, 12: 97-108. 
زيادة تفضيل الخنافس الداكنة

Akis subtricostata Redtenbacher, 1850

Trachyderma philistina Reiche and Saulcy, 1857 ,

(Coleoptera, Tenebrionidae)

اللنباتات مع زيادة درجة الحرارة

عمر ك. اسماعيل و آرون بارثولوميو

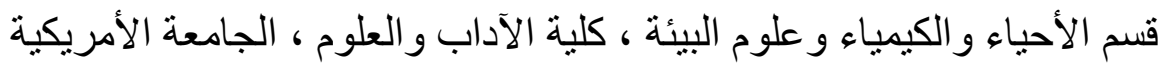

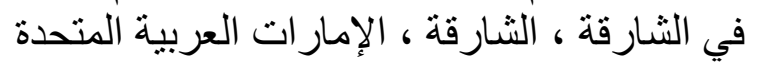

تأريخ الاستلام: 2020/05/25، تاريخ القبول: 2020/06/18، تأريخ النشر: 2020/06/24

\section{الخلاصة - ماصة}

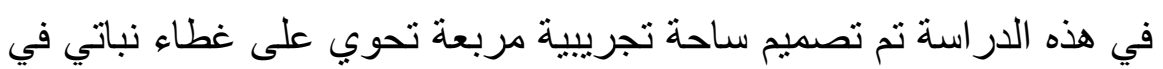

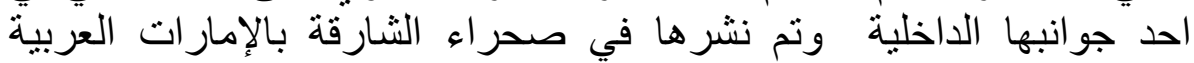

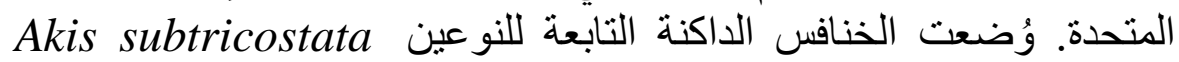
Trachyderma philistina Reiche and و Redtenbacher, 1850 Saulcy, 1857 داخل الساحة عند درجات حرارة تتراوح بين 27-49 درجة التحئ

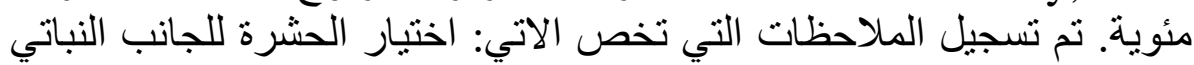

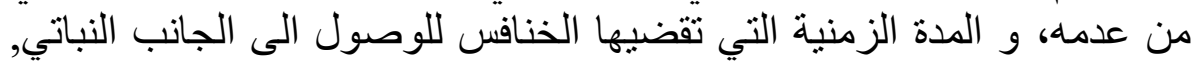
في حال نم اخْتيارِهِ.

فضل كلا النوعين الجانب النباتي في جميع درجات الحرارة ، و إزْدادتُ إندان

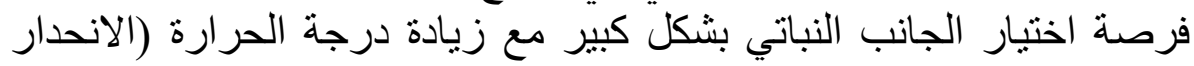
A. T. philistina ل اللوجستي ، Subtricostata

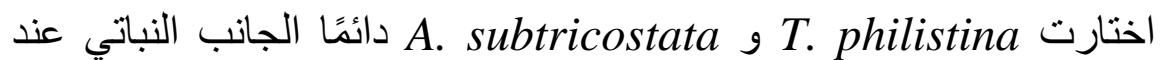

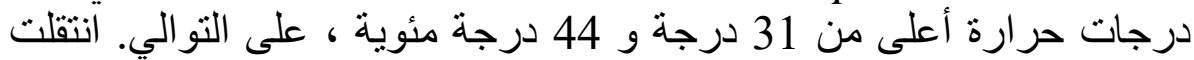

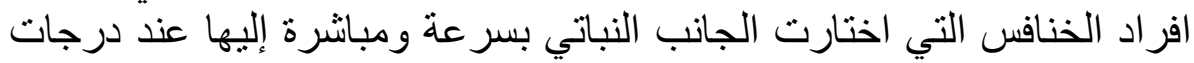


Ismail and Bartholomew

حرارة أعلى من 30 درجة مئوية. تميل الخنافس تحت 30 درجة مئوية إلى الى التى

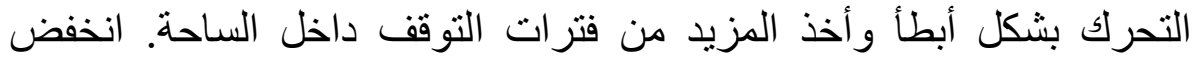

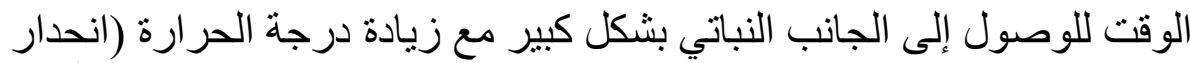

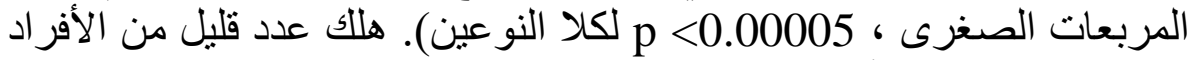
من كلا النو عين عند أعلى درجات الحرارة (49-48 درجة مئوية). 